$$
\begin{aligned}
& \text { 豊富な環境で生育するととによる } \\
& \text { シロネズミの一般的活動性の増大 }{ }^{1)}
\end{aligned}
$$

$$
\text { 岡山大学法交学部 三 谷 恵一 }
$$

生活体の成長（growth）の過程で，その生育する環境が狭く刺激作用（stimulation） が少ない場合よりも, 環境が広く, 玩具や他の生活体の存在などによる変化する刺激作用 が相対的に多い場合の方が，生活体の発達（development）を促進することは，1946年に HEBB and Willlams (12) が動物のための知能検査を開発して以来, HEBB (10) を筆 頭に多くの研究により明らかにされている。このような刺激作用に富む環境は, 自由環境 箱 (free-environment box) ・豊富な環境 (enriched environment) ・複雑な環境 (CE : complex environment)・環境の複雑性と訓練（ECT : environmental complexity and training）などと呼ばれている。

豊富な環境は，第 1 にネズミの知的機能を高めるてとが, НевB $(10,11)$, НyмoviтcH (14), Forgays and Forgays (6), Cooper and Zubek (3), Brown (1), Wilson et al. (33), Sмiтн (29) などにより, Невв-Williams 知能検查法 $(12,25)$ を用いて明ら かにされた。

第 2 に, KRech et al. (15), Rosenzweig (26) やローゼンツバイクら (27) は, ECT は, ネズミの CNS において，大脳皮質の重量を増大させ，またアセチルコリンエステ ラーゼ $(\mathrm{AChE})$ という酵素の量の増加汃ら推定されるシナプス伝達物質としてのアセチ ルコリン $(\mathrm{ACh})$ の増加という解剖学的・化学的変化を見出している。

第 3 亿, 豊富な環境と活動性 (activity) の変化の問題が近年研究されてきている。 WILson et al. (33) は, ネコを生後46日から90日まで, 日に5 時間複雑な環境に入れる という経験が, Hевв-Williams 迷路のエラーを減少させるだけではなく, open field の 活動性を増大させるととを見出し, Manosevitz (16), Manosevitz and Montemayor (18), Manosevitz and Joel (17) は, マウスを生後0日から35日までの初期に豊富な 環境で育てると， open field などの活動性を増大させるととを見出している。

しかし，ネズミを用いた場合，Denenberg and Morton (5) は，自由環境は open field の活動性に変化を見出さず, Smith (29) は, 豊富な環境は, Heвb-Williams 迷路 のエラーを減少させるが， open field の活動性は，個室で育つという淛限された環境 (restricted environment) 群のネズミの方が増大するという逆の結果を見出している。

1) 、本実験は, 1973年度岡山大学法文学部心理学教室上級実験として, 筆者ら 9 名が実施 したものであり，一部は日本心理学会第38回大会シンポジウムで発表された (24)。 
本論文では，シロネズミを用いて，豊富な環璄で生育するという経験が, open field 亿 おける活動性を增大させるととを明らかにし，あわせて動物の open-field behavior の 本質に関する一資料を得るととを目的とする。

\section{方法}

被験体 岡山大学法文学部心理学動物実験室の近交系純系 Wistar シロネズミ27匹を 使用した。

装置 (1) 豊富な環境 ${ }^{2}$ ：Fig. 1 亿平面罒を示したような内径 $1,000 \times 1,000 \times 450 \mathrm{~mm}$ の大きなケイジ 1 基。側面・天井・床は, すべて金網が張られている。ケイジのれは， 複雑なトンネル, シーソー, ブランコ, 高さ $250 \mathrm{~mm}$ の一部二階, はしごなどがあり, コーナーには，日本クレア繁殖用固型飼料と水とが常時与えられている。

ての豊富な環境は，1973年 9 月から1974年 2 月にかけて，3,000×6,000 m m の飼育室 の中に設置され, 照明は自然採光とし, 室内の温度は $23^{\circ} \mathrm{C} \pm 3^{\circ}$ に, 湿度は $60 \%$ に保たれ ていた。

(2) Open field: Denenberg and Morton (5), Denenberg (4)に準じ, 1, $000 \times 1,000$ $\times 450 \mathrm{~mm}$ のベニヤ板製の open field を使用した。装置は黒色に塗装され， $200 \mathrm{~mm}$ 間 隔で白線が縦横に引かれて，広場は25個の区画に分けられている。照明は，広場面より高 さ $2,100 \mathrm{~mm}$ の $40 \mathrm{w}$ 螢光灯 2 基により，照度はおよそ $80 \mathrm{Lux}$ であった。また実験室の 温度は, $18^{\circ} \mathrm{C}$ に保たれていた。

(3) TKK アクティビティ・ホイール（回転輪） 2 台, および 7 素子記録器 1 台。

（4）石田式ダイヤル動物科 L 12型 1 台。

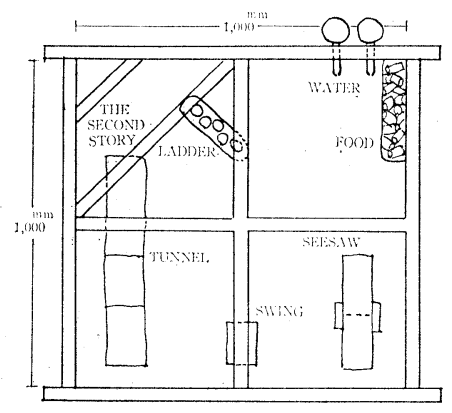

Fig. 1. Floor plan of enriched environment.

手続 [群構式]動物は, 次の 3 群にリターと 性別とに基づき分けられる。実験群々（ $\mathrm{N}=9)$ は, 生後25日から 104 日まで, 豊富な環境のケイ ジで生㕕した。統制群令（N=6）および統制群 ㅇ $(\mathrm{N}=12)$ は， 6 匹ずつ $410 \times 270 \times 150 \mathrm{~mm}$ の金網製の集団飼育箱で生育する。水と飼料は; 常に与えられる。なお，25日の離乳時までは，全 動物は統制群と同じケイジで出生し, 生育した。

〔体重測定（80日間)〕生後25日より35日まで は2 日目でとに，35日よりテスト終了の104日ま では 3 日目でとに，以後は 1 週間目でとに，すべ ての動物の体重が測定された。

2) 具体的イメージは KRECH et al. (15, 511頁), ローゼンッバイクら (27, 73頁) を参 照のとと。 
[Open-field test ( 3 日間)] 生後 100 日目の17時から, open-field test により動物 の行動をテストする。動物は, 飼育室より実験室までキャリング・ケイジにて運ばれ, open field に1匹ずつ, 手前の中央の区画を出発点として，5分間放置される。縮尺1/10の 記録紙に， 1 分でとに，動物の次の諸反応を記録する。第 1 亿, 移動活動 (ambulatory activity）の軌跡であり，動物の 4 本の足がある区画に入った場合を移動活動「1」 とした。次に, 排出得点 (elimination scores) として, 排便 (D: defecation) と排尿 $(\mathrm{U}$ : urination) 反応の位置と回数を記録した。

〔回転車輪テスト (2 日間)〕 Open-field testに続 いて，103日目から毎日17時より 20分間, 動物は 1 匹ずつ回転車輪内に放置される。回転車輸は, 一方向にのみ回転するよ うにし，1/5回転で記録器のペンが作動した。また15秒単位で, 時間も記録された。

\section{結果}

〔I〕体重について。動物の体重に関する成長曲線を Fig. 2 に示す。雄の場合, 豊 富な環境で生育した実験群。の方が集団飼育箱で生育した統制群令よりも，体重そのもの の発達は抑制される。生後 110 日の平均体重は, 統制群占は $370.0 \mathrm{~g}$ であるのに対して, 実験群々は $334.2 \mathrm{~g}$ である。また, 統制群の性差は著しく, 統制群+

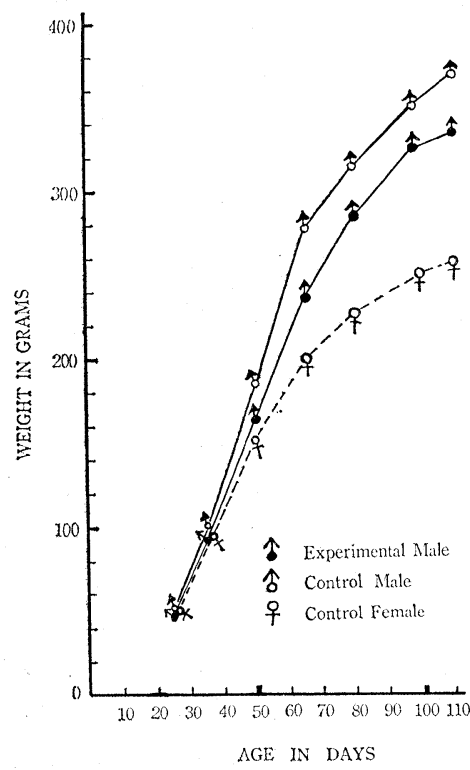

Fig. 2. Growth curve of weight for Wistar strain rat.

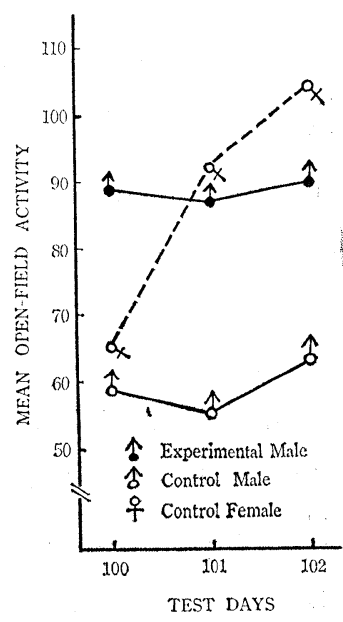

Fig. 3. Mean open-field activity (entries) per 5 minutes. 
Table 1. Analysis of variance of open-field activity in terms of rearing environment and test day.

\begin{tabular}{lrrrc}
\hline \multicolumn{1}{c}{ Source } & SS & $d f$ & MS & $F$ \\
\hline Environment & $6,724.0$ & 1 & $6,724.0$ & $8.03^{*}$ \\
Error (a) & $8,369.9$ & 10 & 837.0 & \\
& & & & $<1$ \\
Test Days & 183.8 & 2 & 91.9 & $<1$ \\
ExTD & 151.1 & 2 & 75.6 & \\
Error (b) & $2,133.8$ & 20 & 106.7 & \\
\hline Total & $17,562.6$ & 35 & & $* p<.05$
\end{tabular}

Table 2. Analysis of variance of open-field activity in terms of sex and test day.

\begin{tabular}{lrrrr}
\hline \multicolumn{1}{c}{ Source } & \multicolumn{1}{c}{ SS } & $d f$ & MS & \multicolumn{1}{c}{$F$} \\
\hline Sex & $13,572.2$ & 1 & $13,572.2$ & $26.5^{* *}$ \\
Error (a) & $5,117.4$ & 10 & 511.7 & \\
& & & & $12.8^{* *}$ \\
Test Days & $6,544.2$ & 2 & $3,272.1$ & $9.1^{* *}$ \\
SxTD & $4,640.7$ & 2 & $2,320.3$ & \\
Error (b) & $5,099.5$ & 20 & 255.0 & \\
\hline Total & $34,974.0$ & 35 & & $*$ \\
\hline
\end{tabular}

〔II]Open-field test の移動活動数について。

（1）豊富な環境の效果. 各群の平均移動活動数を Fig. 3 に示す。実験群占と統制群令 とのそれぞれの個体数を $\mathrm{N}=6$ に統一した雄のみの移動活動数に関する分散分析を Table 1 に示す。実験群々は，統制群占よりも，活動性は有意に高い $(F=8,03, d f=1 \& 10$, $p<.05)$ 。

（2）性差 移動活動数の性差に関する分散分析を, 統制群令と統制群早の個体数を $\mathrm{N}=6$ に統一して Table 2に示す。雌の動物は，3 日間の open-field test の総計に関しては, 活動性は雄よりも有意に高い $(F=26.52, d f=1 \& 10, p<.01)$ 。但し，統制群 93 日間 の検查日による活動性の増大が有意であり $(F=12.83, d f=2 \& 20, p<.01)$, また性差と 検查日との交互作用も有意である $(F=9.10, d f=2 \& 20, p<.01)$ 。

（3）検査日別 1 分単位移動活動数 Fig. 4 は，3 日間のそれぞれの 5 分間の検查におけ 
る平均移動活動数の 1 分どとの推移を群別に示している。実験群々は，100日からの3日 間を通じて，第 1 分の活動性が最大で，時間の経過とともに次第に減少する。また，検査 日による変化や，検查日と時間との交互作用がないことが注目される。統制群今は，第 1 分に関しては，第 1 日目がもっとも少ない。102 日に入って，実験群っのようなパターン を示すが，絶対量はより少ない。統制群早は，日を追うにつれて第 1 分目の活動性が増大 してゆき, 絶対量も増大した。

〔III] Open-field test の排便反応について。各群の平均排便反応数を Table 3 に示 す。各群において，「第 2 分目」に排便反応数が最大であるととが分る。生育環境による 有意差はない。

〔IV] Open-field test の排尿反応について。各群の平均排尿数を Table 4 に示す。 各群において，「第 1 分目」に排尿反応数が最大であるととが分る。生育環境による有意 差はない。

[V] 回転車輸テストについて。103日と 104 日における各群の平均回転数を Fig. 5 に 示す。実験群」は, 統制群合よりも回転数は多い傾向にあるが, 開平変換後 $(\sqrt{X+.5})$ の分散分析でも有意差はない。但し, 生育環璄と検查日との交互作用は有意である $(F=$ $5.64, d f=1 \& 10, p<.05)$ 。

次に統制群だけの同様の分散分析の結果, 統制群早の回転数は, 統制群今よりも有意に 著しく高い $(F=59.47, d f=1 \& 10, p<.001)$ 。

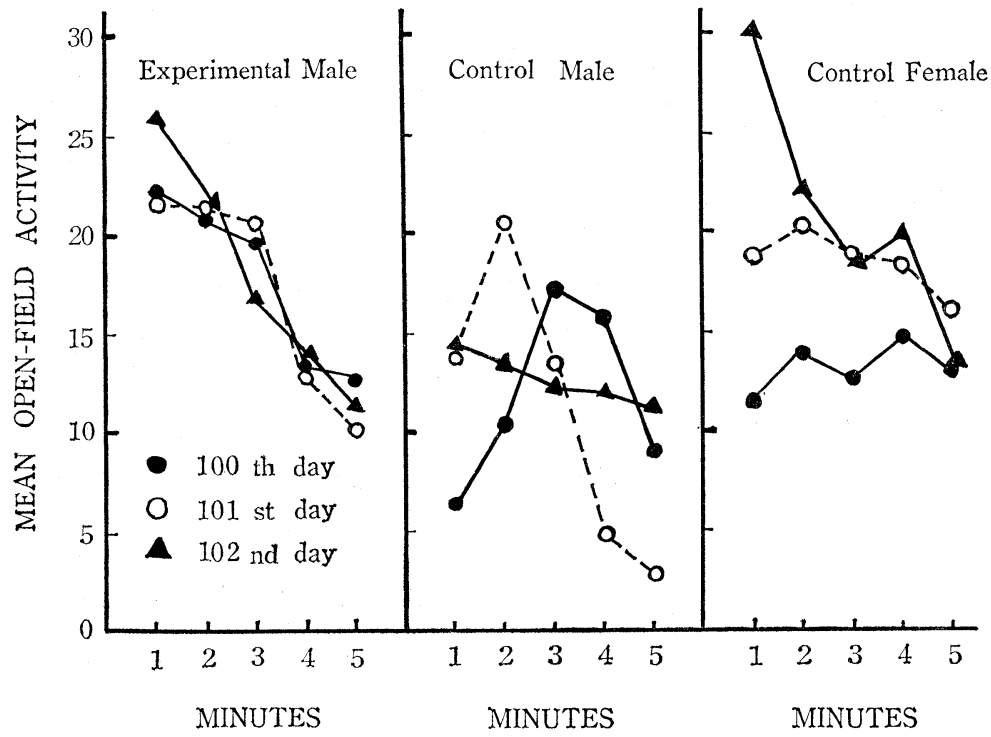

Fig. 4. Mean open-field activity (entries) per minute in each test day. 

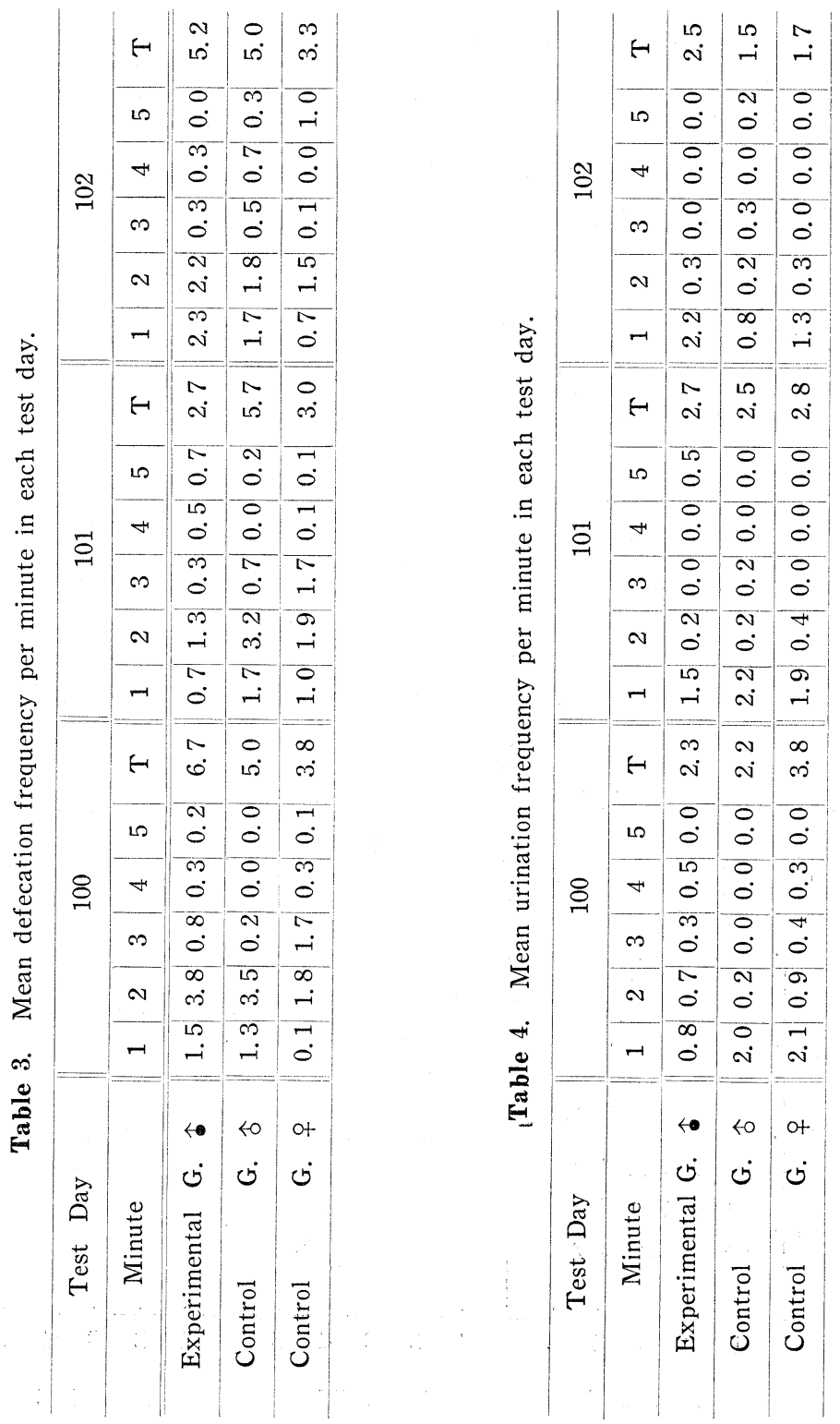


\section{考察}

生後25日から100日までの75日閒に，“豊富 な環境”で生育した実験群っのシロネズミは, open-field test の結果, Fig. 3のように, 通常 の集时飼育箱で生育した統制群占よりも活動性 が有意に高かった。シロネズミによる以上の結 果は, ネコを用いた WILson et al. (33) やマ ウスを用いた Manosevitz (16), Manosevitz and Montemayor (18), Manosevitz and Joel (17）の結果と一致している。

しかしながら，シロネズミを用いて DENEN BERG and MORTON(5)は, 統制群との間にopen field の活動性に差を見出さず, Sмiтн (29) は, 逆に統制群の方が活動性が $5 \%$ 水準で有意に高 いてとを見出している。乙の矛盾は，如何に考 察するととができるであろうか。

まず S MITH（29）の実験では，統制群の動物 は22日から55日まで個別飼育という制限された 環境で生育していることが指摘される。生活体 を，個別飼育ないしは隔離 (isolation) のよう な制限された環境で生育した場合にも， open field の活動性が増大するととを, MeLzACK

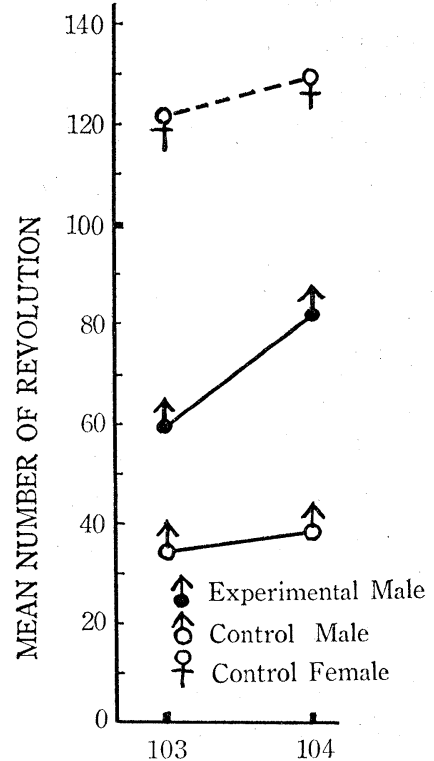

TEST DAYS

Fig. 5. Mean number of revolutions in the activity wheel per 20 minutes (onefifth unit). $(19,20)$ はスコッティシュ・テリアを用いて，藤田・原（7）はヒヨコを用いて，三谷 (24)はシロネズミを用いて示している。また ZIMbardo and Montgomery (36) は, 制 限された環境のネズミに「探索的活動 (exploratory behavior)」が増大するという単純 な表現をしてはいるが，活動性が増大するととを指摘し，Woods（34）は同様の動物が HebB-Williams 知能検查の目標箱に達しても, 飳を食べずに retracing behavior を示 す個体が多いてとを観察している。 $\operatorname{MeLzACK}(19,20)$ は，制限された環境で生育した動 物は, 散漫な情緒的興奮を示し, open field に出されると最初は身体を固くしたり (freeze), うずくまったり (crouch) するが，検査日が進むにつれて次第に統制群の動物よりも著 しく活動的となるととを示している。三谷 $(24)$ も，シロネズミを用いて同様の資料を示し ている。三谷 $(23,24)$ は，乙の現象を DENE NBERG (4) のブラウン運動という表現にな らい, 生活体の中のネガティブなものの顕現した活動性の増大と考察して, 多動 (hyperactivity) と表現した。 
つまり, 活動性には二面性があり ${ }^{3)}$, 積極的移動性としての一般的活動性（general activity）と，情緒不安定を伴った消極的移動性としての多動とに区则できると仮定した $(23,24)$ 。一般的活動性を増大させる経験とは，ハンドリング $(31)$, 定時給食 $(35)$, 社会 的相互作用 (5), HeBB-Williams 知能検査の繰り返し $(21,22)$, 特定の学㿢経験 (23) な ぞである。そして本実験により，シロネズミにおいても，豊富な環境で生育するととによ り一般的活動性が増大するととが明らかにされた。参考資料として，RosEnZwEIG (26) は，大きなケイジでも物体 (objects) のない環境や動物のグループの大きさが小さいと， 活動性が相対的に抑制されるととを見出している。なお，シロネズミを用いて，統制群と の間に open-field test の活動性に差を見出さなかった Denenberg and Morton (5) の 結果は, 離乳時から25日間のみ豊富な環境を提供し検査は生後 180 日以後であるため, 初 期経験効果の消去が生じている可能性があるとと，統制群も集団飼育であるため，多動は 生じていないなどの理由が考学られる。

体重に関しては, Fig. 2のように, 豊富な環境の方が統制群より少ないてとはROSENZWEIG et $a l$. （28）と同じ結果であり，運動により引き締まった身体になると考えられる。

性差に関しては, open-field testでは Fig. 3 のように, 統制群早の方が，統制群令よ り多移動活動は有意に高い。乙の結果は, BROADHURST (2) や細田 (13) と同様である。 また回転車輸テストでは Fig. 5 のように, 統制群早は統制群占よりも一貫して活動性が 著しく䯩い。

しかしながら, Fig. 3 と Fig. 4 より明らかなととは, open field の統制群早の活動性 は，検査の第1日目は統制群令と差がないが，Table 2 から明らかなように，統制群早 の活動性は検查日を追うて有意に増大してゆき，性差と検査日との交互作用も有意であ るととの意味の考察が必要であろう。Fig. 3 の統制群早のグラフは, すでに考察した Melzack (20，68頁，Fig. 1) の実験で，制限された環境で生育したスコッディュ・ テリアが，検査日を追うにつれて著しく多動になってゆく资とよく類似している。また， 三谷（24）の個別飼育のシロネズミの活動性が検査日を追うにつれて増大してゆく姿とも 類似している。そして第 4 日, 第 5 日と慣れた時点で, 新奇ではあるが薄暗く㹨い回転車 輪に20分間という open field の 4 倍の時間放置すると, Fig. 5 のように 統制群早の活動 性は, 統制群含よりも一貫して著しく有意に高い。STEWART (30) は, 多動児(hyperactive children) を研究して，母親によって “德魔”のようであると表現されている子供が，新 奇な精神科医の事務所に連れててられたその時には，“天使”のようにおとなしいという 二重性ないしは行動の激変性を指摘している。そのメカニズムとして, 新奇事態のような ストレスが脳細胞に少量のノルエピネフリン (norepinephrine) やノルアドレナリン

3) Whimbey and Denenberg (32) は open field に打ける活動性は, “情動的反応怢 (emotional reactivity)”と“探索 (exploration)”の二つの独立因子に負荷量を持 つととを明らかにした。 
(noradrenalin) の分泌をうながし，脳幹網様体を媒介して一時的に多動を抑制すると仮 定している。従って, 䧳の動物の活動性が雄よりも高いととの本質は, 筆者の定義によれ ば一般的活動性が高いのか多動の傾向があるのかは, 残された課題の一つである。

最後に Table 3 および Table 4 より, open fieldの排便と排便に関しては, 実験群。 と統制群令とでは差がないととが分る。統制群早では，排便は一貫して少ない傾向にある が，排尿は検查 1 日目に多い傾向にある。BROADHURST (2) は，雌の動物は open field の排便頻度が有意に少ないととを見出している。また Table 3 と Table 4 から明らか なように，排便は第 2 分目に最大で，排尿は第 1 分目に最大であることは，HALL $(8,9)$ がネズミの情動性 (emotionality) 每毎日 2 分間の open-field testで，また本実験と同様 のopen field を用いた Denenberg and Morton (5) が每日3分間という短時間で検查し ていることの妥当性を示している。

要約

シロネズミの雄 9 匹を，生後 25 日から104日まで $1,000 \times 1,000 \times 450 \mathrm{~mm}$ の“豊富な環 境”で生育させると， $410 \times 270 \times 150 \mathrm{~mm}$ の集団飼育で生育した統制群の雄 6 匹に比較し て, 生後 100 日から 3 日間実施された open-field test の活動性を有意に増大させるてと が明らかにされた。Defecationお よび Urination には有意差はなかった。統制群の雌の 12匹は，第 1 日目は統制群の雄と変わらない活動性を示すが，2 日目と 3 日目とで急激に 増大を示し，103 日から 2 日間実施された回転車輪テストでは，著しい活動坐を示した。

\section{REFERENCES}

1. Brown, R. T. Early experience and problem-solving ability. J. Comp. physiol. Psychol., 1968, 65, 433-440.

2. Broadhurst, P. L. Determinants of emotionality in the rat. I. Situational factors. Brit. J. Psychol., 1957, 48, 1-12.

3. Cooper, R. M. and Zubek, J. P. Effects of enriched and restricted early environments on the learning ability of bright and dull rats. Canad. J. Psychol., 1958, 12, 159-164.

4. Denenberg, V.H. Experimental programming of life histories in the rat. In Ambrose, A. (Ed.) Stimulation in early infancy. Academic Press, 1969.

5. Denenberg, V. H. and Morton, J. R. C. Effects of environmental complexity and social groupings upon modification of emotional behavior. $J$. comp. physiol. Psychol., 1962, 55, 242-246.

6. Forgays, D. G. and Forgays, J. W. The nature of the effect of free environmental experience in the rat. J. comp. physiol. Psychol., 1952, 45, 322-328. 
7. 藤田統・原正隆 ヒヨコの open-field 行動に及ぼす初期飼育条件と日令の影響. 動心年報 $1971,21,31-42$.

8. HALL, C. S. Emotional behavior in the rat. I. Defecation and urination as measures of individual differences in emotionality. J. comp. Psychol., 1934, 18, 385-403.

9. HALL, C. S. Emotional behavior in the rat. III. The relationship between emotionality and ambulatory activity. J. comp. Psychol., 1936, 22, 345-352.

10. Невв, D. O. The effects of early experience on problem solving at maturity. American Psychologist, 1947, 2, 306-307.

11. Невв, D. O. The organization of behavior; a neuropsychological theory. Wiley, 1949.

12. Невв, D. O. and Williams, K. A method of rating animal intelligence. J. general Psychol., 1946, 34, 59-65.

13. 細田和雅 オープン・フィールドにおけるネズミの行動. 岡山大学教育学部研究集録, 1971, 31, 45-71.

14. Hyмолітсн, B. The effects of experimental variations on problem solving in the rat. J.comp. physiol. Psychol., 1952, 45, 313-321.

15. Krech, D., Rosenzweig, M. R. and Bennet, E. L. Effects of environmental complexity and training on brain chemistry. J.comp. physiol. Psychol., 1960, $53,509-519$.

16. Manosevitz, M. Early environmental enrichment and mouse behavior. J. comp. physiol. Psychol., 1970, 71, 459-466.

17. Manosevitz, M. and Joel, U. Behavioral effects of environmental enrichment in randomly bred mice. J. comp. physiol. Psychol., 1973, 85, 373-382.

18. Manosevitz, M. and Montemayor, R. J. Interaction of environmental enrichment and genotype. J. comp. physiol. Psychol., 1972, 79, 67-76.

19. Melzack, R. The genesis of emotional behavior: An experimental study of the dog. J. comp. physiol. Psychol., 1954, 47, 166-168.

20. Melzack, R. Early experience: A neuropsychological approach to heredityenvironment interactions. In Newton, G. and Levine, S. (Eds.) Early experience and behavior. Springfield. III : Chales C. Thomas. 1968.

21. 三谷恵一 HeBb-Williams 知能検査法のシロネズミによる再検討. 動心年報, 1962, 12, 21-31.

22. 三谷恵一 初期学習における経験と発達のメカニズム. 京都大学学位論文, 1972 (未 公刊)。 
23. 三谷恵一・安藤正文・永田 博 学習によるシロネズミの一般的活動性の増大. 動 心年報, 1972, 22, 21-26.

24. 三谷恵一 活動性と経験との 関連について. 日本心理学会第38回大会発表論文集 1974, 105-106.

25. Ravinovitch, M. S. and Rosvold, H. E. A closed field intelligence test for rat. Canad. J. Psychol., 5, 122-128.

26. Rosenzweig, M. R. Effects of environment on development of brain and of behavior. In Tовасн, E., Aronson, L. R. and Shaw, E. (Eds.) The biopsychology of develoment. Academic Press, 1971.

27. ローゼンツバクイ, M. R., ベネット, E. L. ダイアモンド（今村護郎訳）経験がひ きおてす脳の変化. 日本経済新聞社, サイエンス Scientific American 1972, 4,7280 .

28. Rosenzweig, M. R., Krech, D., Bennetr, E. L. and Diamond, M. C. Modifying brain chemistry and anatomy by enrichment or impoverishment of experience. In Newton, G. and Levine, S. (Eds.) Early experience and behavior. Springfield. III : Chales C. Thomas. 1968.

29. Sмгтн, H. V. Effects of environmental enrichment on open-field activity and Hebb-Williams problem solving in rats. J.comp. physiol. Psychol., 1972, 80, $163-168$.

30. Stewart, M. A. Hyperactive children. Scientific American, 1970, 222, 94-99.

31. Weininger, $O$. The effects of early experience on behavior and growth characteristics. J.comp. physiol. Psychol., 1956, 49, 1-9.

32. Whimbex, A. H. and Denenberg, V. H. Two independent behavioral dimensions in open-field performance. J.comp. physiol. Psychol., 1967, 63, 500-504.

33. Wilson, M., Warren, J. M. and Аввотт, L. Infantile stimulation, activity, and learning by cats. Child Development, 1965, 36, 843-853.

34, Woods, P. J. The effects of free and restricted environmental experience on problem-solving behavior in the rat. J. comp. physiol. Psychol., 1959, 52, 399-402.

35. 八木 冕 シロネズミの一般的活動性の変容に及ぼす諸条件の研究. I. 定時給食 の効果. 動心年報, 1961, 11, 93-102.

36. Zimbardo, P. G. and Montgomery, K. C. Effects of "free environment" rearing upon exploratory behavior. Psychol. Rep., 1957, 3, 589-594. 


\title{
Abstract \\ Enhancement of General Activity through Rearing in Enriched Environment in the White Rat
}

\author{
Keirchi Mitani
}

Okayama University

To examine increase in general activity through rearing in enriched environment, an experiment was performed with using 15 male rats and 12 female rats immediately after weaning. Nine experimental male animals were reared from 25 to 104 -day-old in the enriched environment cage measured $1,000 \times 1,000 \times 450 \mathrm{~mm}$ covered with wire netting (Fig. 1). Six control male animals and 12 control female animals were reared 6 in group in the standard laboratory group cage measured $410 \times 270 \times 150 \mathrm{~mm}$ covered with wire netting.

One hundred-day-old animals were subjected to 5 minutes Denenberg $(4,5)$ type open-field test for 3 days. It was found that experimental male animals were significantly more active than the control male animals (Fig. 3, Table 1). Control female amimals were also significantly more active than the control male animals (Fig. 3, Table 2). Control female animals ambulated as equally as male control, however, in the first test day. Their activity increased significantly as the test day proceeded. Sex $\times$ test days interaction was also significant. There was no significant enrichment effect in open-field defecation and urination scores (Table 3, Table 4).

On fourth and fifth days, behavior was measured in the activity wheel for 20 minutes. Although it did not reached level of significance, experimental male animals were more active than control male (Fig. 5). Enrichment $\times$ test days interaction was significant. Control female ran extremely greater than the control male and the difference was highly significant. Lastly, the growth curve of weight indicated that control male were heavier than experimental male (Fig. 2).

In discussion, reasons for contradictory result of Sмiтн (29), namely control rats were more active in open-field test, were considered. It was pointed out that Sмrтh (29) restricted control animals in individual cages. Restriction increases also open-field activity as Melzack $(\mathbf{1 9}, 20)$, Fujita and Hara (7) and Mitani 
(24)' s results.

It was concluded that "enrichment" increases general activity, namely psychologically positive activity, and "restriction" produces hyperactivity, namely psychologically negative activity. This suggestion is also found in Whimber and Denenberg (32)'s two factor theory of open-field activity and Mitani (23, 24)'s implication. 